\title{
Actibacterium mucosum gen. nov., sp. nov., a marine alphaproteobacterium from Mediterranean seawater
}

\author{
Teresa Lucena, María A. Ruvira, Esperanza Garay, M. Carmen Macián, \\ David R. Arahal and María J. Pujalte
}

Correspondence

María J. Pujalte

maria.j.pujalte@uv.es

\author{
Departamento de Microbiología y Ecología and Colección Española de Cultivos Tipo (CECT), \\ Universidad de Valencia, Valencia, Spain
}

\begin{abstract}
Strain $\mathrm{R} 6^{\top}$, a marine alphaproteobacterium, was isolated from Mediterranean seawater at Malvarrosa beach, Valencia, Spain. It is an aerobic chemo-organotrophic, mesophilic and slightly halophilic organism, with complex ionic requirements. Phylogenetic analyses based on the $16 \mathrm{~S}$ rRNA and gyrB gene sequences showed that strain R46 ${ }^{\top}$ formed a separate branch within the family Rhodobacteraceae, bearing similarities below 94.7 and $80.3 \%$, respectively, to any other recognized species. It contained $\mathrm{Q} 10$ as the predominant isoprenoid quinone and $\mathrm{C}_{18: 1} \omega 7 \mathrm{c} /$ $\mathrm{C}_{18: 1} \omega 6 c$ as the major cellular fatty acid. Phosphatidylglycerol was the only identified polar lipid, although other lipids were also detected. The DNA G+C content of the genomic DNA was $61.3 \mathrm{~mol} \%$. On the basis of extensive phenotypic and phylogenetic comparative analysis, it is concluded that the strain represents a novel genus and species, for which the name Actibacterium mucosum gen. nov., sp. nov. is proposed. The type strain of the type species is Actibacterium mucosum R46 ${ }^{\mathrm{T}}$ (=CECT $7668^{\mathrm{T}}=\mathrm{KCTC} 23349^{\mathrm{T}}$ ).
\end{abstract}

The family Rhodobacteraceae in the class Alphaproteobacteria of the phylum Proteobacteria mainly comprises bacteria of aquatic origin, many of them requiring $\mathrm{NaCl}$ for growth. Within this family, the so-called Roseobacter group is one of the most abundant and ubiquitous. Since the description of the genus Roseobacter over two decades ago (Shiba, 1991), this group has expanded to include more than 54 genera, as can be seen in the release (LTPs106_SSU) of the Living Tree Project database (Yarza et al., 2010).

Strain $\mathrm{R} 46^{\mathrm{T}}$ was isolated from surface seawater collected at

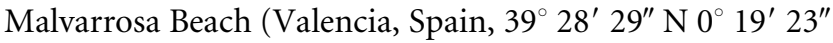
$\mathrm{W}$; temperature $25{ }^{\circ} \mathrm{C}$; $\mathrm{pH} 8.0$ ) in July 2008. Seawater was plated directly on Marine R2A agar, and incubated at $26{ }^{\circ} \mathrm{C}$ for 8 days, after which isolated colonies were randomly selected and restreaked on the same medium

Abbreviations: ASW, artificial sea water; DPG, diphosphatidylglycerol; PC, phosphatidylcholine; PHB, polyhydroxybutyrate; MALDI-TOF, matrixassisted desorption/ionization time of flight; $\mathrm{ML}$, maximum-likelihood; MP, maximum-parsimony; NJ, neighbour-joining; $P G$, phosphatidylglycerol; $\mathrm{PE}$, phosphatidylethanolamine.

The GenBank/EMBL/DDBJ accession numbers for the gyrB gene sequences of Palleronia marisminoris CECT $7066^{\top}$, strain R46 ${ }^{\top}$, Jannaschia seosinensis CECT 7799 ${ }^{\top}$, Maribius salinus CECT $7800^{\top}$, Jannaschia donghaensis CECT $7802^{\top}$, Oceanicola nanhaiensis CECT $7831^{\top}$ and Oceanicola pacificus CECT $7832^{\top}$ are HE590587HE590593, and that of the $16 \mathrm{~S}$ rRNA gene of strain R46 ${ }^{\top}$ is HE590855.

Six supplementary figures are available with the online version of this paper. until pure cultures were obtained. Marine R2A agar was prepared with R2A agar (Difco) using aged, filtered seawater as the suspending fluid instead of distilled water. Strain $\mathrm{R} 46^{\mathrm{T}}$ showed good growth on marine broth $(\mathrm{MB}$; Difco) and marine agar (MA, MB plus $1.2 \%$ bacteriological agar; Oxoid). Thus, for routine use, the strain was subsequently cultured on MA or in $\mathrm{MB}$ at $28{ }^{\circ} \mathrm{C}$ for $2-$ 4 days. It was stored at $-80{ }^{\circ} \mathrm{C}$ in $\mathrm{MB}$ supplemented with $20 \%(\mathrm{v} / \mathrm{v})$ glycerol. Strain $\mathrm{R} 46^{\mathrm{T}}$ was deposited in CECT and KCTC as CECT $7668^{\mathrm{T}}$ and KCTC $23349^{\mathrm{T}}$, respectively.

A 1000 bp region of the $16 S$ rRNA gene (Arahal et al., 2008) of strain R46 ${ }^{\mathrm{T}}$ was obtained and a BLAST search in public databases (Zhang et al., 2000) suggested that this strain represented a new taxon within the alphaproteobacteria branch containing members of the genus Roseobacter and related marine bacteria. Therefore, strain $\mathrm{R} 46^{\mathrm{T}}$ was submitted to a taxonomic study using a polyphasic approach, including classical biochemical and physiological characterization, chemotaxonomic and phylogenetic analyses, using almost complete (1412 bp) 16S rRNA and partial (1000 bp) gyrB gene sequences. The following type strains were included in the study and tested under the same conditions: Pseudoruegeria aquimaris CECT $7680^{\mathrm{T}}$, Jannaschia rubra CECT $5088^{\mathrm{T}}$, Jannaschia helgolandensis DSM $14858^{\mathrm{T}}$, Jannaschia donghaensis CECT $7802^{\mathrm{T}}$, Jannaschia seosinensis CECT $7799^{\mathrm{T}}$, Palleronia marisminoris CECT $7066^{\mathrm{T}}$, Maribius salinus CECT $7800^{\mathrm{T}}$ and Thalassobacter stenotrophicus CECT $5294^{\mathrm{T}}$. 
The cell morphology and motility of strain $\mathrm{R} 46^{\mathrm{T}}$ were examined on wet mounts under phase-contrast microscopy (DMRB fluorescence microscope; Leica). Half-strength artificial sea water (ASW; $400 \mathrm{mM} \mathrm{NaCl}, 100 \mathrm{mM}$ $\mathrm{MgSO}_{4} \cdot 7 \mathrm{H}_{2} \mathrm{O}, 20 \mathrm{mM} \mathrm{KCl}$ and $20 \mathrm{mM} \mathrm{CaCl}_{2} \cdot 2 \mathrm{H}_{2} \mathrm{O}$ ) was used as the suspension medium. Cells grown on MA plates for $48 \mathrm{~h}$ were rod-shaped and non-motile. Inclusion bodies or granules were not seen. The absence of polyhydroxybutyrate (PHB) accumulation was also noted in cells grown on MA and basal medium agar [BMA; $50 \mathrm{mM}$ Tris/ $\mathrm{HCl}$, $\mathrm{pH}$ 7.5; $19 \mathrm{mM} \mathrm{NH}_{4} \mathrm{Cl} ; 0.33 \mathrm{mM} \mathrm{K}_{2} \mathrm{HPO}_{4} .3 \mathrm{H}_{2} \mathrm{O} ; 0.1 \mathrm{mM}$ $\mathrm{FeSO}_{4} \cdot 7 \mathrm{H}_{2} \mathrm{O}$ and $1.3 \%$, w/v, purified agar (Oxoid) on halfstrength ASW (Baumann \& Baumann, 1981)] plus pyruvate for 7 days at $25{ }^{\circ} \mathrm{C}$ that were stained with Nile Blue A (Smibert \& Krieg, 1994). T. stenotrophicus CECT $5294^{\mathrm{T}}$ was used as a positive control. The cell size and morphology of strain $\mathrm{R} 46^{\mathrm{T}}$ were also determined by using scanning electron microscopy at the Servicio Central de Soporte a la Investigación Experimental (University of Valencia, Spain). Samples were examined in an Hitachi S-4100 field emission scanning microscope with a 7-15 $\mathrm{mm}$ working distance and at an acceleration voltage of $10 \mathrm{kV}$ (Fig. S1, available in IJSEM Online). Cells were ovoid to rod-/club-shaped, with moderate tendencies to aggregate. The size of the cells was $0.2-0.5 \times 0.6-1.4 \mu \mathrm{m}$. Cells lysed readily when suspended in $3 \%(\mathrm{w} / \mathrm{v}) \mathrm{KOH}$ solution, indicating that the strain was Gram-negative. Strain $\mathrm{R} 6^{\mathrm{T}}$ grows on MA as regular, mucous, non-pigmented, non-luminescent colonies.

The biochemical and physiological profile of the strain along with reference type strains was determined, in duplicate, in two independent assays. The ability to grow at different temperatures was tested on MA incubated at $4{ }^{\circ} \mathrm{C}$ ( 15 days), $15{ }^{\circ} \mathrm{C}$ (15 days), 28, 37, 40 and $45{ }^{\circ} \mathrm{C}$ $(48 \mathrm{~h})$. The strain grew from 15 to $37{ }^{\circ} \mathrm{C}$, while no growth was ever observed at 4 or $40{ }^{\circ} \mathrm{C}$. Ionic requirements were tested on salt tolerance agar (STA), containing $1 \%$ peptone, $0.3 \%$ yeast extract and $1.2 \%$ purified agar. This medium was supplemented with the following salt combinations (in w/v): (i) with and (ii) without $2 \%$ $\mathrm{NaCl}$, (iii) with $2 \% \mathrm{KCl}$, (iv) with $2 \% \mathrm{NaCl}$ and $0.9 \%$ $\mathrm{MgCl}_{2} \cdot 6 \mathrm{H}_{2} \mathrm{O}$, (v) with $2 \% \mathrm{NaCl}$ and $0.2 \% \mathrm{CaCl}_{2} \cdot 2 \mathrm{H}_{2} \mathrm{O}$, (vi) with $2 \% \mathrm{NaCl}$ and $0.06 \% \mathrm{KCl}$, (vii) with $2 \% \mathrm{NaCl}$, $0.9 \% \mathrm{MgCl}_{2} \cdot 6 \mathrm{H}_{2} \mathrm{O}$ and $0.2 \% \mathrm{CaCl}_{2} \cdot 2 \mathrm{H}_{2} \mathrm{O}$, (viii) with $2 \% \mathrm{NaCl}, 0.9 \% \mathrm{MgCl}_{2} .6 \mathrm{H}_{2} \mathrm{O}, 0.2 \% \mathrm{CaCl}_{2} .2 \mathrm{H}_{2} \mathrm{O}$ and $0.06 \% \mathrm{KCl}$, (ix) with $2 \% \mathrm{NaCl}, 0.9 \% \mathrm{MgSO}_{4} \cdot 7 \mathrm{H}_{2} \mathrm{O}$, $0.2 \% \mathrm{CaCl}_{2} \cdot 2 \mathrm{H}_{2} \mathrm{O}$ and $0.06 \% \mathrm{KCl}$. The ionic requirements were complex, as the strain did not grow on media with only $\mathrm{NaCl}$ or $\mathrm{KCl}$ added, or with the various combinations of $\mathrm{NaCl}$ and $\mathrm{Mg}, \mathrm{Ca}$ and $\mathrm{K}$ chlorides. Good growth was obtained only when STA was supplemented with $\mathrm{NaCl}, \mathrm{CaCl}_{2}, \mathrm{KCl}$ and $\mathrm{MgSO}_{4}$ or when the full combination of marine salts was present (as in MA or seawater-based media). The salinity range for growth was tested on MA as reported previously (Macián et al., 2005a) and it was $1-5 \%(\mathrm{w} / \mathrm{v})$ total salinity.

The strain was positive in oxidase and catalase tests. It was unable to ferment glucose in $\mathrm{O} / \mathrm{F}$ medium supplemented with ASW. Acid from glucose was not produced aerobically. Nitrate reduction to nitrite or further products was tested in marine nitrate broth, with an inverted Durham tube for the detection of gas production, and also in API 20NE strips; negative results were always obtained. Other enzymic activities also tested for by two methods (classical and API 20NE) were: arginine dihydrolase (Baumann \& Baumann, 1981), indole production from tryptophan (in MB) and glucose fermentation; however, all these tests were negative. Hydrolysis of casein, alginate, starch and lecithin was tested on MA as basal medium and after 6 days of incubation (as recommended by Baumann \& Baumann, 1981). Tween-80 hydrolysis was tested on medium containing $1 \%$ peptone, $0.01 \% \mathrm{CaCl}_{2}, 1 \%$ Tween- 80 and $1.2 \%$ agar powder, supplemented with marine cation supplement (MCS; Farmer \& Hickman-Brenner, 2006), while DNase activity was tested on DNase agar (Oxoid), also prepared with MCS. Gelatin hydrolysis was assayed in API 20NE and was positive after $48 \mathrm{~h}$ of incubation. Sole carbon and energy sources used for growth were investigated on BMA supplemented with carbohydrates, organic acids or amino acids and incubated for up to 14 days. API 20NE and API ZYM profiles were obtained for strain $\mathrm{R} 46^{\mathrm{T}}$ and reference strains by following the manufacturer's instructions, except for the inclusion of MCS in the suspension medium. In API 20NE, conventional tests were read after $24 \mathrm{~h}$ incubation but assimilation and gelatin tests were reincubated for an additional $24 \mathrm{~h}$ after the first reading. The results of strain $\mathrm{R}^{\mathrm{T}} \mathrm{T}^{\mathrm{T}}$ were negative for all tests, except for gelatin and aesculin hydrolysis (48 h). In API ZYM, strain $R 46^{\mathrm{T}}$ was positive only for leucine arylamidase and gave a weak result in the alkaline phosphatase reaction. Results of Biolog GN2 microplates (inoculated by using ASW-based suspension fluid) were erratic. Consistent positive results were only obtained for the oxidation of the following substrates: cellobiose, L-rhamnose, D-sorbitol, turanose, citric acid, $\alpha$-ketovalerate, propionic acid, quinic acid, succinic and bromo-succinic acids, alaninamide, Dserine, glucose 1-phosphate and glucose-6-phosphate.

Fatty acid methyl esters were extracted from biomass grown for $48 \mathrm{~h}$ on $\mathrm{MA}$ at $28{ }^{\circ} \mathrm{C}$ and prepared according to standard protocols as described for the MIDI Microbial Identification System (Sasser, 1990) at the CECT. Cellular fatty acid content was analysed by GC with an Agilent 6850 chromatographic unit, with the MIDI Microbial Identification System using the RTSBA6 method (MIDI, 2008) and identified using the Microbial Identification Sherlock software package. Twelve different cellular fatty acids were detected in strain $\mathrm{R} 46^{\mathrm{T}}$, two hydroxylated, six saturated and four unsaturated. The main component was $\mathrm{C}_{18: 1}$, which accounted for $75.3 \%$ of the total, as occurs in all species so far analysed in the Roseobacter group. Other components are shown in Table 1, along with the results obtained in parallel with some reference type strains. The presence of $\mathrm{C}_{12: 0}$ $3-\mathrm{OH}$ in appreciable amounts $(4.6 \%)$ is a distinctive feature of the fatty acid profile of strain $\mathrm{R} 46^{\mathrm{T}}$.

Analysis of respiratory quinones and polar lipids was carried out by the Identification Service of the DSMZ and 
Table 1. Comparison of cellular fatty acid composition of $\mathrm{R} 46^{\top}$ and related species

Taxa: 1, strain R46 ${ }^{\mathrm{T}} ; 2$, Pseudoruegeria aquimaris CECT $7680^{\mathrm{T}}$; 3, J. donghaensis CECT $7802^{\mathrm{T}} ; 4$, J. helgolandensis DSM $14858^{\mathrm{T}}$; 5 , Jannaschia rubra CECT $5088^{\mathrm{T}}$; 6, J. seosinensis CECT $7799^{\mathrm{T}}$; 7, Palleronia marisminoris CECT $7066^{\mathrm{T}} ; 8$, Maribius salinus CECT $7800^{\mathrm{T}}$; 9, Thalassobacter stenotrophicus CECT $5294^{\mathrm{T}}$. All data are from this study. - , Not detectable; tr, trace amount $(<1 \%)$. Cellular fatty acid composition carried out according to the Microbial Identification System (Microbial ID) using cultures grown on MA for $48 \mathrm{~h}$ at $28{ }^{\circ} \mathrm{C}$. Fatty acids giving only trace amounts or not detected for all strains are not represented.

\begin{tabular}{|c|c|c|c|c|c|c|c|c|c|}
\hline Cellular fatty acid (\%) & 1 & 2 & 3 & 4 & 5 & 6 & 7 & 8 & 9 \\
\hline \multicolumn{10}{|l|}{ Hydroxy } \\
\hline $\mathrm{C}_{10: 0} 3-\mathrm{OH}$ & 8.1 & 4.5 & 4.0 & 7.2 & 3.5 & 3.4 & 3.8 & 6.1 & 5.0 \\
\hline $\mathrm{C}_{12: 0} 3-\mathrm{OH}$ & 4.6 & - & - & - & - & - & - & - & - \\
\hline \multicolumn{10}{|l|}{ Saturated } \\
\hline $\mathrm{C}_{9: 0}$ & - & - & - & 1.1 & $\operatorname{tr}$ & - & - & - & - \\
\hline $\mathrm{C}_{12: 0}$ & 1.0 & $\operatorname{tr}$ & - & $\operatorname{tr}$ & $\operatorname{tr}$ & - & - & $\operatorname{tr}$ & $\operatorname{tr}$ \\
\hline $\mathrm{C}_{14: 0}$ & $\operatorname{tr}$ & $\operatorname{tr}$ & - & 1.7 & $\operatorname{tr}$ & - & 1.4 & - & 1.0 \\
\hline $\mathrm{C}_{16: 0}$ & 8.3 & $\operatorname{tr}$ & $\operatorname{tr}$ & 3.2 & 2.5 & 1.0 & 2.7 & 4.3 & 1.7 \\
\hline $\mathrm{C}_{17: 0}$ & $\operatorname{tr}$ & $\operatorname{tr}$ & $\operatorname{tr}$ & $\operatorname{tr}$ & $\operatorname{tr}$ & $\operatorname{tr}$ & $\operatorname{tr}$ & 1.6 & 2.2 \\
\hline $\mathrm{C}_{18: 0}$ & 1.4 & 4.1 & 5.4 & 9.6 & 7.9 & 6.0 & 3.1 & 2.3 & 2.8 \\
\hline $\mathrm{C}_{18: 0}$ iso & - & - & $\operatorname{tr}$ & - & $\operatorname{tr}$ & - & 1.9 & - & 19.6 \\
\hline $\mathrm{C}_{19: 0}$ & - & - & 2.6 & 1.0 & - & $\operatorname{tr}$ & - & - & - \\
\hline $\mathrm{C}_{19: 0}$ cyclo $\omega 8 \mathrm{c}$ & - & 1.4 & - & 15.1 & - & - & 14.7 & 5.4 & - \\
\hline \multicolumn{10}{|l|}{ Unsaturated } \\
\hline $\mathrm{C}_{17: 1}$ iso $\omega 9 c$ & - & - & - & - & - & - & - & - & 1.2 \\
\hline $\mathrm{C}_{18: 1} \omega 7 c$ 11-methyl & 1.3 & 3.0 & 3.9 & 4.9 & $\operatorname{tr}$ & - & - & 4.0 & 2.5 \\
\hline $\mathrm{C}_{18: 1}$ iso $\mathrm{H}$ & - & - & - & - & 8.8 & - & - & - & - \\
\hline $\mathrm{C}_{18: 1} \omega 9 c$ & - & - & - & - & - & - & - & - & 2.7 \\
\hline $\mathrm{C}_{20: 1} \omega 7 c$ & $\operatorname{tr}$ & $\operatorname{tr}$ & 2.8 & $\operatorname{tr}$ & $\operatorname{tr}$ & $\operatorname{tr}$ & - & - & - \\
\hline $\mathrm{C}_{20: 2} \omega 6,9 c$ & - & - & - & 1.2 & $\operatorname{tr}$ & - & 1.0 & - & - \\
\hline \multicolumn{10}{|l|}{ Summed feature } \\
\hline $2\left(\mathrm{C}_{14: 0} 3-\mathrm{OH} / \mathrm{C}_{16: 1}\right.$ iso $\left.\mathrm{I}\right)$ & - & - & - & 2.5 & $\operatorname{tr}$ & 1.6 & - & - & - \\
\hline $3\left(\mathrm{C}_{16: 1} \omega 7 c / \mathrm{C}_{16: 1} \omega 6 c\right)$ & $\operatorname{tr}$ & $\operatorname{tr}$ & - & - & $\operatorname{tr}$ & $\operatorname{tr}$ & - & $\operatorname{tr}$ & 1.0 \\
\hline $7\left(\mathrm{C}_{19: 1} \omega 7 c / \mathrm{C}_{19: 1} \omega 6 c\right)$ & - & - & 1.4 & 1.3 & - & - & - & 1.6 & $\operatorname{tr}$ \\
\hline $8\left(\mathrm{C}_{18: 1} \omega 7 c / \mathrm{C}_{18: 1} \omega 6 c\right)$ & 73.1 & 81.9 & 77.1 & 49.2 & 72.1 & 85.5 & 70.7 & 73.4 & 59.0 \\
\hline
\end{tabular}

Dr B. J. Tindall, DSMZ, Braunschweig, Germany. Strain $\mathrm{R} 46^{\mathrm{T}}$ had a ubiquinone (Q10) system, in agreement with reported data for other members of the Roseobacter clade, and the following polar lipids: phosphatidylglycerol (PG), two aminolipids, two phospholipids, three lipids and one glycolipid (Fig. S2).

Sample preparation for matrix-assisted laser desorption/ ionization time-of-flight (MALDI-TOF) MS protein analysis was carried out at the CECT, according to the ethanol/ formic acid extraction protocol recommended by Bruker Daltonics (http://www.bdal.de). MALDI-TOF MS was conducted using a Reflex IV mass spectrometer (Bruker Daltonics) equipped with an $\mathrm{N}_{2}$ laser. All spectra were recorded in linear positive ion mode. The acceleration voltage was $20 \mathrm{kV}$. Spectra were collected as a sum of 240 shots across a spot, and between 12-16 spots per strain. A mass range of $2-20 \mathrm{kDa}$ was used for analysis. Peak recognition and comparison of the spectra were done with the BioTyper software 1.1 as described by Maier et al. (2006). The dendrogram obtained with MALDI-TOF MS illustrates that strain $\mathrm{R} 46^{\mathrm{T}}$ can be well separated from the type strains of the following species: J. helgolandensis DSM $14858^{\mathrm{T}}$, J. rubra CECT $5088^{\mathrm{T}}$, J. seosinensis CECT $7799^{\mathrm{T}}$, J. donghaensis CECT $7802^{\mathrm{T}}$, M. salinus CECT $7800^{\mathrm{T}}$, Palleronia marisminoris CECT $7066^{\mathrm{T}}$, Phaeobacter inhibens CECT $7251^{\mathrm{T}}$, Phaeobacter gallaeciensis CECT $7277^{\mathrm{T}}$, Phaeobacter daeponensis CECT $7309^{\mathrm{T}}$, Roseobacter litoralis CECT $5395^{\mathrm{T}}$, Roseobacter denitrificans CECT $5011^{\mathrm{T}}$, Roseovarius crassostreae CECT $7676^{\mathrm{T}}$, Roseovarius aestuarii CECT $7745^{\mathrm{T}}$, Roseovarius tolerans CECT $7738^{\mathrm{T}}$, Roseovarius nubinhibens CECT $7750^{\mathrm{T}}$, Pseudoruegeria aquimaris CECT $7680^{\mathrm{T}}$ and $T$. stenotrophicus CECT $5294^{\mathrm{T}}$ (Fig. S3).

The DNA G + C content, determined by the Identification Service of the DSMZ using HPLC according to the method described by Tamaoka \& Komagata (1984) and Mesbah et al. (1989), was $61.3 \mathrm{~mol} \%$.

Cell pellets were collected and DNA was extracted using a microbial DNA isolation kit (Ultra Clean, Mo Bio Laboratories). Amplification of $16 \mathrm{~S}$ rRNA and gyrB genes was performed as described previously (Lucena et al., 2010; Pascual et al., 2010). PCR amplicons were purified using an UltraClean PCR clean-up kit (Mo Bio Laboratories). Subsequent sequencing reactions were carried out on an ABI PRISM 3730 automated sequencer using the Big Dye 
Terminator v3.1 cycle sequencing kit, premixed format. The sequencing primers were the same ones used in the amplification reaction but diluted tenfold ( $5 \mathrm{pmol})$. The new sequences were compared with public sequences in the EMBL gene databases using the BLAST program (National Center for Biotechnology Information; http://www.ncbi.nlm. nih.gov/). Related sequences were further analysed using the ARB program package (Ludwig et al., 2004) (http://www.arbhome.de). Automated sequence alignments were corrected manually using the ARB_EDIT sequence editor. 16S rRNA gene sequence alignments retrieved from SILVA and LTP latest updates were also used as references (Pruesse et al., 2007; Yarza et al., 2010). Phylogenetic analysis using alternative treeing methods (maximum-parsimony, MP, maximum-likelihood, ML, and distance matrix) and data subsets were performed using the appropriate ARB tools (Ludwig et al., 2004).

The 16S rRNA gene sequence analysis showed that even the highest similarities were below $95 \%$. Oceanicola nitratireducens $\mathrm{JLT}_{1210^{\mathrm{T}}}$, Poseidonocella sedimentorum KMM $9025^{\mathrm{T}}$, Shimia isoporae $\mathrm{SW}-6^{\mathrm{T}}$ and Vadicella arenosi $\mathrm{KMM}$ $9024^{\mathrm{T}}$ displayed $94.7 \%$ similarity to strain $\mathrm{R} 46^{\mathrm{T}}$, whereas Pseudoruegeria aquimaris SW- $255^{\mathrm{T}}$ had $94.4 \%$, Roseibacterium elongatum JCM $11220^{\mathrm{T}} 94.3 \%$ and Shimia marina CL$\mathrm{TA}^{\mathrm{T}} \mathrm{3}^{\mathrm{T}}$ and $J$. donghaensis DSW $-17^{\mathrm{T}}$ exhibited $94.2 \%$. All other members of the family Rhodobacteraceae shared less than $94.0 \%$ similarity to strain R $46^{\mathrm{T}}$. Given the low similarity values, tree topology considering alternative treeing methods was taken into account as a better indicator of relatedness. The gyrB gene sequence retrieved from strain $\mathrm{R} 6^{\mathrm{T}}$ showed similarities lower than $80.0 \%$ when compared with the available gyrB sequences from Rhodobacteraceae, with the single exception of Roseovarius nubinhibens ( $80.3 \%$ similarity).

Phylogenetic analyses performed using all three methods (neighbour-joining, NJ, MP and ML) and both $16 \mathrm{~S}$ rRNA and $g y r B$ genes always placed strain $\mathrm{R} 46^{\mathrm{T}}$ in a separate lineage, only distantly related to neighbour taxa within the Roseobacter clade (Figs 1, S4, S5 and S6). In the case of the trees based on the 16S rRNA gene, the genera Jannaschia, Maribius, Palleronia and Hwanghaeicola appear as the closest relatives of strain $\mathrm{R} 46^{\mathrm{T}}$ (supported by resemblance in topology and high resampling values in the connecting nodes). Although gyrB trees showed differences in the phylogenetic inference with respect to the $16 \mathrm{~S}$ rRNA trees, it has to be noted that it is based on a smaller set of species and that possible recombination events cannot be accurately evaluated with the present data. In any case, it gives further support to the recognition of strain $\mathrm{R} 46^{\mathrm{T}}$ as a new taxon within the Roseobacter clade.

All together, the information gathered for strain $\mathrm{R} 46^{\mathrm{T}}$ in this study indicates that it belongs to a yet unrecognized genus of marine alphaproteobacteria, that can be differentiated from members of the Roseobacter group, and for which the name Actibacterium mucosum gen. nov., sp. nov. is proposed.

The new genus can be phenotypically differentiated from the nearest genera on the basis of polar lipid composition, DNA
$\mathrm{G}+\mathrm{C}$ molar content, maximum halotolerance, $\mathrm{PHB}$ production, oxidase activity and motility behaviour. Thus, the genera Jannaschia, Roseovarius, Litoreibacter, Celeribacter and Vadicella differ in the presence of phosphatidylethanolamine (PE) and phosphatidylcholine (PC) (plus diphosphatidylglycerol, DPG, in some instances) in their cells, while these polar lipids are absent in strain $\mathrm{R} 46^{\mathrm{T}}$. In addition, members of the genus Celeribacter are motile and oxidase-negative, those of the genus Vadicella are able to reduce nitrates, and most species of the genus Roseovarius have a high halotolerance (up to $15 \%$ salinity). Differences with the genus Thalassobacter include the presence in this genus of PC and DPG and accumulation of PHB. One of the two members of the genus Pseudoruegeria ( $P$. aquimaris) could be differentiated by the polar lipids PC, PE and DPG, while the other (P. lutimaris) is readily differentiated by the presence of fatty acid $\mathrm{C}_{19: 0}$ cyclo and a much higher $\mathrm{G}+\mathrm{C}$ mol\%. Members of the genus Maribius show a different halotolerance pattern, being able to grow with up to $10-15 \%$ salinity (maximum salinity allowing growth of strain $\mathrm{R}^{\mathrm{T}} 6^{\mathrm{T}}$ is $5 \%$ ), accumulate $\mathrm{PHB}$ and have a DNA G+C content from 67 to $70 \mathrm{~mol} \%$. Members of the genus Palleronia are negative for oxidase, accumulate PHB and grow at $15 \%$ salinity, unlike those of the genus Actibacterium. Finally, members of the genus Hwanghaeicola are motile cocci differing from species of the genus Actibacterium in traits such as pigmentation, indole production, $\beta$-galactosidase activity, Voges-Proskauer reaction and a different cellular fatty acid composition that includes $\mathrm{C}_{19: 0}$ cyclo but not $\mathrm{C}_{12: 0}$ 3-OH. Additional differentiation of strain $\mathrm{R} 46^{\mathrm{T}}$ from the type strains of several species of the Roseobacter clade is shown in Table 2.

\section{Description of Actibacterium gen. nov.}

Actibacterium (Ac.ti.bac.te'ri.um. L. n. acta, ae seaside, shore; -i- connecting vowel; L. neut. n. bacterium a small rod; N.L. neut. n. Actibacterium a rod from the seaside).

Aerobic chemo-organotroph with complex ionic requirements. Positive for oxidase and catalase. Does not accumulate PHB. The major polar lipids are PG, an unidentified aminolipid and an unidentified lipid. The major cellular fatty acids are $\mathrm{C}_{18: 1} \omega 7 c / \mathrm{C}_{18: 1} \omega 6 c$. The predominant isoprenoid quinone is Q10. The DNA G+C content of the type species is $61.3 \mathrm{~mol} \%$. The type species is Actibacterium mucosum.

\section{Description of Actibacterium mucosum sp. nov.}

Actibacterium mucosum (mu.co'sum. L. neut. adj. muсоsum slimy, mucous, a property of the colonies).

In addition to the features included in the genus description above, strain $\mathrm{R} 46^{\mathrm{T}}$ shows the following traits: cells are non-motile and oval- to rod-shaped (0.6-1.4 $\mu \mathrm{m}$ long and $0.2-0.5 \mu \mathrm{m}$ wide). It grows on $\mathrm{MA}$ as regular, mucous and unpigmented colonies, measuring $2 \mathrm{~mm}$ diameter after 4 days of incubation at $28^{\circ} \mathrm{C}$. Growth occurs at $15-37{ }^{\circ} \mathrm{C}$, but not at 4 or $40{ }^{\circ} \mathrm{C}$. Optimal growth 


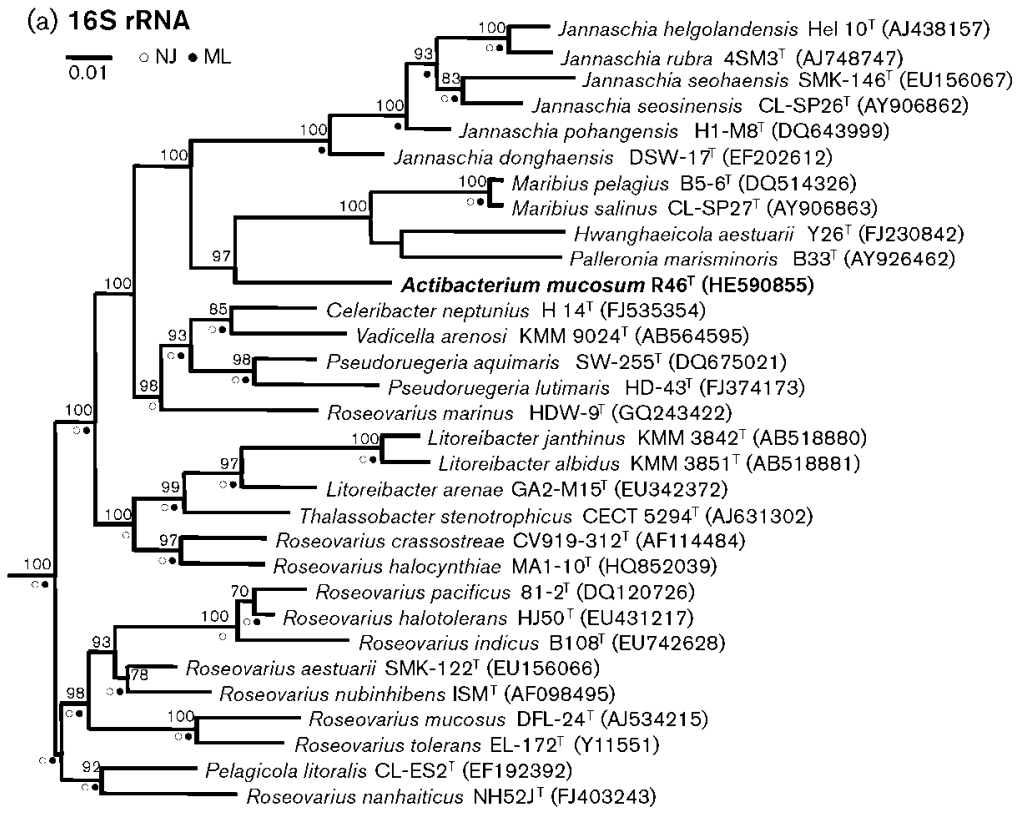

(b) $g y r B$

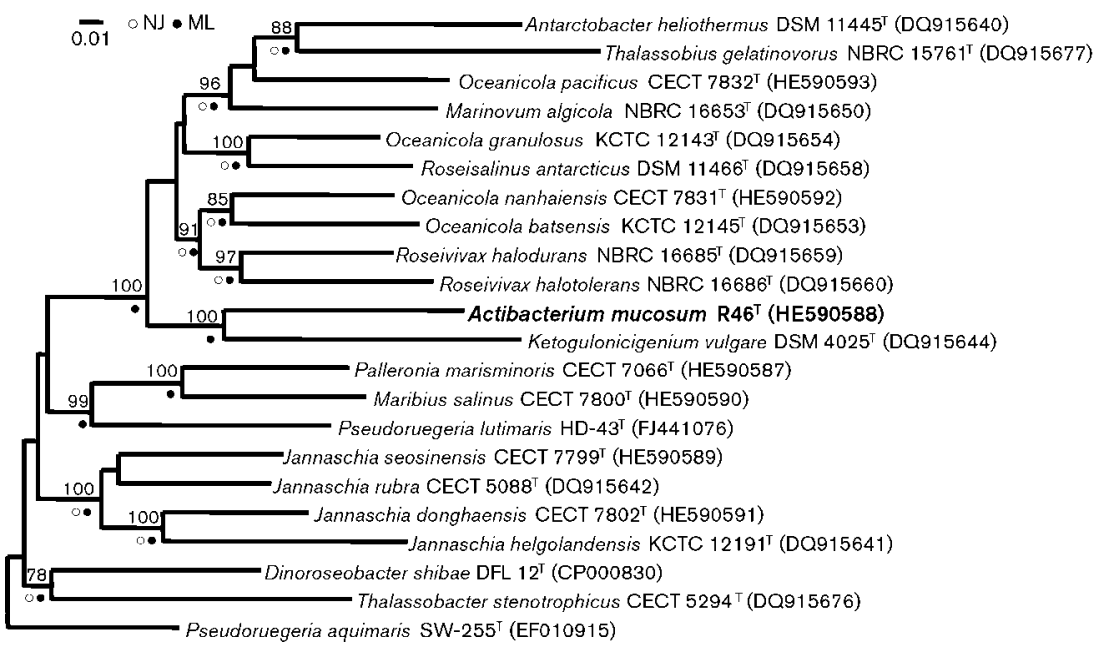

Fig. 1. MP phylogenetic trees based on almost complete 16S rRNA (a) and partial gyrB gene (b) sequences of strain R46 ${ }^{\top}$ (=CECT $7668^{\top}$ ) and closely related species. The $16 \mathrm{~S}$ rRNA tree is a subtree of the one shown in Fig. S6. GenBank accession numbers are given in parentheses. Bootstrap values $\geqslant 70 \%$ confidence are shown at branching points (percentage of 1000 resamplings). Nodes coincident in the $\mathrm{ML}$ and $\mathrm{NJ}$ trees are indicated by a filled circle and an empty circle, respectively. Bar, number of substitutions per position. requires the presence of $\mathrm{Na}^{+}, \mathrm{K}^{+}, \mathrm{Ca}^{2+}, \mathrm{Mg}^{2+}$ and $\mathrm{SO}_{4}{ }^{2-}$ ions or the addition of seawater to the medium. The salinity range for growth on MA is $1.7-5 \%$; no growth is produced at $6 \%$ or more, or below $1 \%$ salinity. It does not ferment carbohydrates and is not able to reduce nitrate to nitrite or further. It is also negative for the following activities: arginine dihydrolase, indole production from tryptophan, PNPG, urease, aesculin, casein, starch, alginate, lecithin, DNA hydrolysis, esterase (C4), esterase lipase (C8), lipase (C14), cystine arylamidase, trypsin, $\alpha$-chymotrypsin, acid phosphatase, naphthol-AS-BI-phosphohydrolase, $\alpha$-galactosidase, $\beta$-galactosidase, $\beta$-glucuronidase, $\alpha$-glucosidase, $N$-acetyl- $\beta$-glucosaminidase, $\alpha$-mannosidase and $\alpha$-fucosidase. Gelatin is hydrolysed after 2 days. Alkaline phosphatase and leucine arylamidase are positive or weakly positive. The strain grows on defined medium (BMA) using the following sole carbon and energy sources:
D-ribose, D-xylose, D-glucose, D-fructose, D-galactose, Dmannose, cellobiose, glycerol, D-glycerate, myo-inositol, acetate, pyruvate, propionate (slow), butyrate, citrate, 2oxoglutarate, succinate, fumarate, malate, lactate, 3-hydroxybutyrate and L-tyrosine. The ability to grow with sucrose, lactose, melibiose, D-sorbitol, L-alanine and L-glutamate is variable. No growth is obtained with the following carbon sources: L-arabinose, L-rhamnose, salicin, amygdalin, $\mathrm{N}$ acetyl-D-glucosamine, D-gluconate, D-glucuronate, D-galacturonate, D-mannitol, saccharate, aconitate, glycine, L-leucine, L-serine, L-threonine, L-arginine, L-ornithine, Lcitrulline, L-4-aminobutyrate, L-aspartate, L-lysine, L-histidine, L-sarcosine or putrescine. Polar lipid composition includes phosphatidyl glycerol, two unidentified aminolipids, three unidentified lipids, two unidentified phospholipids and one unidentified glycolipid. Major cellular fatty acids are $\mathrm{C}_{18: 1} \omega 7 c / \omega 6 c, \mathrm{C}_{16: 0}, \mathrm{C}_{10: 0} 3-\mathrm{OH}$ and $\mathrm{C}_{12: 0} 3-\mathrm{OH}$. 
Table 2. Differential characteristics between strain $R 46^{\top}$ and some related species

Taxa: 1, strain R46 ${ }^{\mathrm{T}}$; 2, Pseudoruegeria aquimaris CECT $7680^{\mathrm{T}} ; 3$, J. donghaensis CECT $7802^{\mathrm{T}}$; 4, J. helgolandensis DSM $14858^{\mathrm{T}}$; 5 , J. rubra CECT $5088^{\mathrm{T}}$; 6, J. seosinensis CECT 7799 ; 7, Palleronia marisminoris CECT $7066^{\mathrm{T}} ; 8$, M. salinus CECT $7800^{\mathrm{T}}$. All data from this study unless otherwise indicated. + , Positive; -, negative; tr, trace amount.

\begin{tabular}{|c|c|c|c|c|c|c|c|c|}
\hline & 1 & 2 & 3 & 4 & 5 & 6 & 7 & 8 \\
\hline Colony colour & Beige & Greyish yellow & Deep orange & Beige orange & Red & Deep red & Pink & Beige \\
\hline Motility & - & - & - & - & + & + & - & - \\
\hline $37^{\circ} \mathrm{C}$ & + & + & - & - & + & + & + & + \\
\hline $0.25 \%$ salinity & - & + & - & + & + & + & + & + \\
\hline $6 \%$ salinity & - & + & - & - & + & + & + & + \\
\hline D-Glucose & - & + & - & - & + & - & - & - \\
\hline D-Mannose & - & + & - & - & + & - & - & - \\
\hline D-Mannitol & - & + & - & + & + & - & + & $-^{*}$ \\
\hline Maltose & - & + & - & - & - & - & + & - \\
\hline Adipate & - & + & - & - & + & - & + & - \\
\hline Starch & - & - & - & + & - & + & - & $-{ }^{*}$ \\
\hline Gelatin & + & - & - & - & - & - & - & - \\
\hline \multicolumn{9}{|l|}{ Enzymatic activity } \\
\hline Alkaline phosphatase & + & + & + & + & + & + & + & - \\
\hline Acid phosphatase & - & + & + & + & + & - & + & - \\
\hline$\alpha$-Galactosidase & - & - & - & - & + & - & - & - \\
\hline $\begin{array}{l}N \text {-Acetyl- } \beta \text { - } \\
\text { glucosaminidase }\end{array}$ & - & + & - & - & - & - & - & - \\
\hline$\alpha$-Glucosidase & - & - & - & - & + & $-{ }^{*}$ & + & - \\
\hline \multicolumn{9}{|l|}{ Fatty acids (\%) } \\
\hline $\mathrm{C}_{12: 0} 3-\mathrm{OH}$ & 4.6 & - & - & - & - & - & - & - \\
\hline
\end{tabular}

${ }^{\star}$ Results that differ from the original description.

$\dagger$ Data from: a, Yoon et al. (2007a); b, Yoon et al. (2007b); c, Wagner-Döbler et al. (2003); d, Macián et al. (2005b); e, Choi et al. (2006); f, MartínezCheca et al. (2005); g, Choi et al. (2007).

In addition, $\mathrm{C}_{12: 0}, \mathrm{C}_{18: 0}$ and $\mathrm{C}_{18: 1} \omega 7 c$ 11-methyl are also detected in a lower proportion.

The type strain, R46 ${ }^{\mathrm{T}}$ (=CECT $7668^{\mathrm{T}}=$ KCTC $23349^{\mathrm{T}}$ ), was isolated from seawater from the western Mediterranean Sea. The DNA G+C content of the type strain is $61.3 \mathrm{~mol} \%$.

\section{Acknowledgements}

The study has been funded through projects CGL2010-18132BOS (Spanish Ministerio de Ciencia e Innovación) awarded to M.J.P. and GVPROMETEO2012-040 (Generalitat Valenciana) awarded to E. G.

\section{References}

Arahal, D. R., Sánchez, E., Macián, M. C. \& Garay, E. (2008). Value of $r e c N$ sequences for species identification and as a phylogenetic marker within the family "Leuconostocaceae". Int Microbiol 11, 33-39.

Baumann, P. \& Baumann, L. (1981). The marine gram-negative eubacteria: genera Photobacterium, Beneckea, Alteromonas, Pseudomonas and Alcaligenes. In The Prokaryotes, vol. 2, pp. 1302-1331. Edited by M. P. Starr, H. Stolp, H. G. Trueper, A. Balows \& H. Schleger. Berlin, Heidelberg: Springer.

Choi, D. H., Yi, H., Chun, J. \& Cho, B. C. (2006). Jannaschia seosinensis sp. nov., isolated from hypersaline water of a solar saltern in Korea. Int J Syst Evol Microbiol 56, 45-49. 
Choi, D. H., Cho, J. C., Lanoil, B. D., Giovannoni, S. J. \& Cho, B. C. (2007). Maribius salinus gen. nov., sp. nov., isolated from a solar saltern and Maribius pelagius sp. nov., cultured from the Sargasso Sea, belonging to the Roseobacter clade. Int J Syst Evol Microbiol 57, 270275.

Farmer, J. J., III \& Hickman-Brenner, F. W. (2006). The genera Vibrio and Photobacterium. In The Prokaryotes, 3rd edn, pp. 508-563. Edited by M. Dworkin, S. Falkow, E. Rosenberg, K.-H. Schleifer \& E. Stackebrandt. New York: Springer.

Lucena, T., Pascual, J., Garay, E., Arahal, D. R., Macián, M. C. \& Pujalte, M. J. (2010). Haliea mediterranea sp. nov., a new marine gammaproteobacterium. Int J Syst Evol Microbiol 60, 1844-1848.

Ludwig, W., Strunk, O., Westram, R., Richter, L., Meier, H., Yadhukumar, Buchner, A., Lai, T., Steppi, S. \& other authors (2004). ARB: a software environment for sequence data. Nucleic Acids Res 32, 1363-1371.

Macián, M. C., Arahal, D. R., Garay, E., Ludwig, W., Schleifer, K. H. \& Pujalte, M. J. (2005a). Thalassobacter stenotrophicus gen. nov., sp. nov., a novel marine $\alpha$-proteobacterium isolated from Mediterranean sea water. Int J Syst Evol Microbiol 55, 105-110.

Macián, M. C., Arahal, D. R., Garay, E., Ludwig, W., Schleifer, K. H. \& Pujalte, M. J. (2005b). Jannaschia rubra sp. nov., a red-pigmented bacterium isolated from sea water. Int J Syst Evol Microbiol 55, 649653.

Maier, T., Klepel, S., Renner, U. \& Kostrzewa, M. (2006). Fast and reliable MALDI-TOF MS-based microorganism identification. Nature Methods. http://dx.doi.org/10.1038/nmeth870

Martínez-Checa, F., Quesada, E., Martínez-Cánovas, M. J., Llamas, I. \& Béjar, V. (2005). Palleronia marisminoris gen. nov., sp. nov., a moderately halophilic, exopolysaccharide-producing bacterium belonging to the 'Alphaproteobacteria', isolated from a saline soil. Int J Syst Bacteriol 55, 2525-2530.

Mesbah, M., Premachandran, U. \& Whitman, W. B. (1989). Precise measurement of the $\mathrm{G}+\mathrm{C}$ content of deoxyribonucleic acid by highperformance liquid chromatography. Int J Syst Bacteriol 39, 159-167.

MIDI (2008). Sherlock Microbial Identification System Operating Manual, Version 6.1. Newark, DE: MIDI Inc.
Pascual, J., Macián, M. C., Arahal, D. R., Garay, E. \& Pujalte, M. J. (2010). Multilocus sequence analysis of the central clade of the genus Vibrio by using the $16 \mathrm{~S}$ rRNA, recA, pyrH, rpoD, gyrB, rctB and toxR genes. Int J Syst Evol Microbiol 60, 154-165.

Pruesse, E., Quast, C., Knittel, K., Fuchs, B. M., Ludwig, W., Peplies, J. \& Glöckner, F. O. (2007). SILVA: a comprehensive online resource for quality checked and aligned ribosomal RNA sequence data compatible with ARB. Nucleic Acids Res 35, 7188-7196.

Sasser, M. (1990). Identification of bacteria by gas chromatography of cellular fatty acids, MIDI Technical Note 101. Newark, DE: MIDI Inc.

Shiba, T. (1991). Roseobacter litoralis gen. nov., sp. nov., and Roseobacter denitrificans sp. nov., aerobic pink-pigmented bacteria which contain bacteriochlorophyll a. Syst Appl Microbiol 14, 140145.

Smibert, R. M. \& Krieg, N. R. (1994). Phenotypic characterization. In Methods for General and Molecular Bacteriology, pp. 607-654. Edited by P. Gerhardt, R. G. E. Murray, W. A. Wood \& N. R. Krieg. Washington, DC: American Society for Microbiology.

Tamaoka, J. \& Komagata, K. (1984). Determination of DNA base composition by reversed-phase high-performance liquid chromatography. FEMS Microbiol Lett 25, 125-128.

Wagner-Döbler, I., Rheims, H., Felske, A., Pukall, R. \& Tindall, B. J. (2003). Jannaschia helgolandensis gen. nov., sp. nov., a novel abundant member of the marine Roseobacter clade from the North Sea. Int J Syst Evol Microbiol 53, 731-738.

Yarza, P., Ludwig, W., Euzéby, J., Amann, R., Schleifer, K. H., Glöckner, F. O. \& Rosselló-Móra, R. (2010). Update of the All-Species Living Tree Project based on 16S and 23S rRNA sequence analyses. Syst Appl Microbiol 33, 291-299.

Yoon, J.-H., Lee, S. Y., Kang, S. J., Lee, C. H. \& Oh, T. K. (2007a). Pseudoruegeria aquimaris gen. nov., sp. nov., isolated from seawater of the East Sea in Korea. Int J Syst Evol Microbiol 57, 542-547.

Yoon, J.-H., Kang, S.-J., Park, S. \& Oh, T.-K. (2007b). Jannaschia donghaensis sp. nov., isolated from seawater of the East Sea, Korea. Int J Syst Evol Microbiol 57, 2132-2136.

Zhang, Z., Schwartz, S., Wagner, L. \& Miller, W. (2000). A greedy algorithm for aligning DNA sequences. J Comput Biol 7, 203-214. 